\title{
The Moderating Role of Earnings Management on the Relationship between Cash Flow Activities and Stock Returns in the Jordanian Manufacturing Firms
}

Submitted 05/09/20, 1st revision 01/10/20, 2nd revision 09/11/20, accepted 15/12/20

\author{
Sinan Suleiman Abbadi ${ }^{1}$
}

\begin{abstract}
:
Purpose: This study examined the moderating role of earnings management on the relationship between cash flow activities and stock returns among the Jordanian manufacturing firms.

Methodology: Data was collected from 44 companies listed in Amman Stock Exchange for the period 2013-2018. The obtained data was subsequently analyzed using descriptive and multiple linear regression analysis tools of SPSS, version 27.

Findings: This study observed that earnings management, computed as per the modified Jones model of 1995, among the manufacturing firms in Jordan produce no significant influence on the relationship between stock returns and the cash flow activities. Moreover, there was no significant association between cash flow activities and the firms' stock returns. Practical implications: The findings from this study give the management of manufacturing firms more freedom to independently list their stock.

Originality: This paper highlights a pragmatic dissonance between earnings management and cash flow activities and stock returns as demonstrated by the data obtained from the manufacturing firms listed in Amman stock exchange for the period 2013-2018.
\end{abstract}

Keywords: Earnings management, cash flow activities, stock returns.

JEL Codes: M12, G32.

Paper type: Research article.

${ }^{1}$ Faculty of Business, Accounting Department, Balqa'Applied University, e-mail:sinan@bau.edu.jo; 


\section{Introduction}

Corporate performances, success or failure, are well exhibited in cash flow activities presented in financial statements and earnings as two dependent measures (Utomo and Pamungkas, 2018). Arguing from the same concept, Lee (2012) expressed that both internal and external auditors pay close attention to the earnings and cash flow activities which are presented in the firms' cash statements. Operating cash flow activities provide a lucid picture and comprehensive information about the firm's financial status and progress (Habib, 2010). It becomes imperative, thus, to indicate that the future financial performance of a firm highly depend on the standing characteristics of the presented cash flow statement and earnings. Moreover, large amount of empirical evidence have linked cash flow activities to stock returns (Utomo and Pamungkas, 2018; Hastuti, Arfan, and Diantimala, 2018).

Despite the long-rooted dependency on the firms' earnings, a vast amount of evidence has further shown that several managers across the globe, including Jordan engage in opportunistic decretory modifications of corporate earnings (Bhaumik and Gregoriou, 2010; Man and Wong, 2013; Gulzar, 2011; Sun and Rath, 2010), thereby creating a deceitful financial information of the firm. Misreporting of earnings correlate with the inaccurate reporting of the cash flow activities. Earnings management is a longstanding concept in corporate management and performance whose implications continue to raise concerns among certified auditors (Abbad, Hijazi, and Al-Rahahleh, 2016).

According to Healy and Wahlen (1999), "earnings management occurs when managers use judgment in financial reporting in structuring transactions to alter financial reports to either mislead some stakeholders about the underlying economic performance of the company or to influence contractual outcomes that depend on reported accounting numbers." Accordingly, the accountant and the firm manager choose to either raise or lower the company earning, as reported on the books of account, to suit their benefits as to have achieved the organizational goals (Hastuti, Arfan, and Diantimala, 2018). Whereas some evidence have shown that earnings management modulates the relationship between cash flows and stock returns, the evidence from Jordan is critically lacking.

Therefore, by staging a strong dependency on three cash flows activities, this study sought to determine the role of earnings management in the relationship between cash flow activities and stock returns among the selected Jordanian firms listed on Amman stock exchange 2013-2018. To satisfy the outlined aim, the study will pursue a set of six hypotheses:

- The operational cash flow of the company has a significant impact on the value of stock returns.

- The investment cash flow of the company has a significant impact on the value of stock returns. 
- The financial cash flow of the company has a significant impact on the value of stock returns.

- Earnings management is able to moderate the relationship between operating cash flows and stock returns.

- Earnings management is able to moderate the relationship between investment cash flows and stock returns.

- Earnings management is able to moderate the relationship between financial cash flows and stock returns.

\section{Literature Review}

The amount of previous literature examining the entangled relationships between earnings management, cash flow activities and stock returns is broad, spanning both the developed and developing nations alike. The credibility of cash flow activities, through the financial statements bore a wide window through which investors, firm analysts, and creditors use to inspect the financial performance of the given named firms (Al-Shattarat, 2016). Since the establishment of Jordanian Association of Certified Public Accountants (JACPA) in 1988, both the financial and non-financial firms operating in Jordan have bowed to the legal requirements of submitting audited financial statements annually as required by the law (22/1977) (AL-Qatamin and Salleh, 2020).

Various companies have thus complied with the regulations to provide their financial statements under three domains of cash flow; the operating activities, financial activities and investment activities for the continuous assessment of their performance. It is apparent that organizational cash flow activities occupy a significant niche in the firms' prospective performance and future progress (Farshadfar \& Monem, 2013). For the same reason, many researchers have explored the role and significance of operating cash flow among other cash flow activities in the firms' stock returns and other accruals.

\subsection{Cash Flow Activities and Stock Returns}

A recent study conducted by Utomo and Pamungkas (2018) to determine the moderating effect of earnings managements on cash flow activities and stock returns among the selected manufacturing firm in Indonesia reported significant interplay between the three activities; earnings management, cash flow activities and stock returns. Notably, the researchers pointed out that both the operational and financial cash flow activities positively contribute to the firms' stock returns. However, the inverse is reported for the investment cash flow which only give a negative effect on the firms' stock returns.

Comparatively, Luo (2008) also echoes the malleability of stock returns as influenced by cash flow activities of a firm. However, Luo demystified the significance of unusual cash flows activities on stock returns. While, the role and 
impact of cash flow activities on stock returns many seem arguable, an irrefutable amount of literate has ascertained the role (Bradshaw, Richardson, and Sloan, 2006; Jansen, 2020; Santoso, 2018). Operating cash flow has an influence on earnings management as it gives information about the firm's liquidity and ability to obtain asset, invest, and pay debts without necessarily having seeking additional funding options (Hastuti, Arfan, and Diantimala, 2018). Information such as revenue and expenditures also spring from a credible operating cash flow records. Such exposition thus confirms the significance of operating cash flow as a signaling clue to the investors, creditors and other external parities with interest in the firms' financial progress (Dickinson, 2011).

Another study conducted by Fawzi (2015) to determine the relationship between cash flow and financial distress reported a negative correlation between the firms' profitability and financial distress. In the same vein, firms with financial distress are bound to linger in inadequate stock returns (Hackbarth, Haselmann, and Schoenherr, 2015). Moreover, Collins, Hribar and Tian (2014) indicated a significant association between the operating cash flow activities and the firms' stock returns. The same idea has been expressed by many other previous researchers (Kroes and Manikas, 2014; Banimahd and Aliabadi, 2013).

\subsection{The Moderating Role of Earnings Management}

Apart from the interplay between the cash flow activities and stock returns, several studies including Utomo and Pamungkas (2018) have also implicated the role of earnings management in the overall corporate financial status. The amount of evidence is vast in Jordan (Abed, Al-Attar, and Suwaidan, 2012; Alzoubi, 2016; Abbadi, Hijazi, and Al-Rahahleh, 2016). A study conducted by Utomo and Pamungkas (2018) in Indonesia further showed that earnings management has the capacity to reinforce the relationship between both the operational and financial cash flow on stock returns. Nonetheless, earnings management does not influence investment cash flow and the firms' stock returns.

A comprehensive exposition presented by Hastuti, Arfan, and Diantimala (2018) paints earnings management as an opportunistic exhibit of the organizational managers to satisfy self-interests. Earnings management became a matter of critical concern across the globe after the scandal in of the American leading energy firms, Enron Corporation (MacCarthy, 2017). Many other larger enterprise companies of global reputation such as WorldCom and Global Cossing Airlines have equally befell the misappropriations of earnings management (Kuhn and Sutton, 2006; Yen et al., 2007). Such cases spread throughout the globe and a classic case in Indonesian company PT. Indofarma Tbk in 2001 also provide a credible exhibit (Armein, 2012). The company overestimated their sales thereby recording IDR 28.87 trillion ( $\$ 1.9$ billion) when the actual sales were evidently low. 
Earnings management affects the accuracy of stock returns since the nature of "relationship between stock returns and earnings depends on the persistence of a company's earnings" (Utomo and Pamungkas, 2018). Despite such a stance, some scholars have posited otherwise. For instance, Bazrafshan (2016) showed that managers that practice earnings management end up with higher returns. However, going by the conventional principles of stock returns, i.e., actual and expected returns are the building materials for stock returns (Beneish, Lee, and Nichols, 2013), then it becomes intriguing to delve deeper into the entanglement and establish more practical and explicit relationship between the three outlined elements of corporate performance.

\section{Methodology}

This study applied quantitative descriptive methodology to establish the moderating role of earnings management on the relationship between cash flow activities and stock returns in the Jordanian manufacturing firms. Data was collected from 44 manufacturing firms as listed in Amman stock exchange between 2013 and 2018. The three significant cash flow activities were recorded; operating cash flow, financial cash flow, and investment cash flow. The operational definitions for the named variables are outlined below.

- Operational cash flow activities: this variables is regarded as the summation of all the activity that accrue from each of the operations in the cash flow statement.

- Investment cash flow activity: this variable is regarded as the cash flow statement summation of all the recorded investment activities.

- Financial cash flow activity: Cash flow statement summation of all the recorded financial activities

Moreover, stock returns and earnings management, as indicated by the discretionary accruals values, provided by the modified Jones model (1995) were also recorded. As a variable in this study, stock return is regarded as the rate of return (otherwise referred to as return of an investment) that the company or the investor receives in a given financial year. The values of stock returns fluctuates with the changes in the assigned stock prices (Utomo and Pamungkas, 2018). On the same note, the modifier variable, earnings management (DACC), is regarded herein as the discretionary accruals (modified Jones model of 1995).

Discretionary accruals model:

$$
\begin{aligned}
& D A C C_{t}=T A C C_{t}-N D A C C_{t} \\
& \text { TACC }_{\boldsymbol{t}}=\text { Total accruals in year }{ }_{t} \\
& N D A C C_{t}=\text { Non - discretionary accruals }{ }_{t}
\end{aligned}
$$


This study did set specific inclusion criteria for the selection of suitable firms whose data would be used in the analysis. Accordingly, 44 companies with consistent records of cash flow activities on their financial statements between 2013 and 2018 were included. Data was subsequently was analyzed using SPSS, version 27. Two statistical tests were used, the descriptive and linear regression statistical analysis, meet the formulated hypotheses.

\section{Results}

Data output is presented under two categories; the descriptive statistics and linear regression. The descriptive statistics as shown in Table 1 shows non-linear pattern of earnings management among the selected companies, between 2013 and 2018. Nonetheless, the highest and lowest DACC were reported in 2013 (mean=1080382.56) and 2014 (mean=-3925753.53) respectively.

Table 1. Earnings Management

\begin{tabular}{lllll}
\hline \hline & Minimum & Maximum & Mean & Standard Deviation \\
\hline $\mathbf{2 0 1 3}$ & -14843000.11 & 38332999.89 & 1080382.56 & 8147875.87 \\
$\mathbf{2 0 1 4}$ & -73185000.13 & 26854865.99 & -3925753.53 & 16284005.75 \\
$\mathbf{2 0 1 5}$ & -57350000.07 & 12603099.85 & -2105912.50 & 9472679.96 \\
$\mathbf{2 0 1 6}$ & -41154000.11 & 14073999.99 & -1449469.57 & 7448291.46 \\
$\mathbf{2 0 1 7}$ & -68840000.12 & 19197417.75 & -2709044.79 & 11862811.23 \\
$\mathbf{2 0 1 8}$ & -61854000.24 & 19197417.75 & -2300587.87 & 10141872.26 \\
\hline \hline
\end{tabular}

Source: Author.

From Table 1, it is observable that higher extents of earnings management produced a negative effects on the firms' profit among the listed Jordanian companies. Indeed, several other scholars have documented the deceitful effects of earnings management on firms' financial performance (Cupertino, Martinez, and Costa Jr, 2016; Gunny, 2010; Roychowdhury, 2006). Just as Gunny (2010) denoted that earnings management increases companies' volatility, and so is the case reported among the Jordanian manufacturing firms where managers' manipulation activities peaked in 2013 only to result in intense financing activities in the following year.

Stock returns was reported to fluctuate unpredictably among the manufacturing firms listed in Amman stock exchange between 2013 and 2018. The listed companies reported highest and lowest mean values of stock returns in 2014 (.1308) and 2015 (-.1197), thereby showing a sharp transition between 2014/2015. Significantly, there are slight overall fluctuations from 2013 to 2018 as reported by the low standard deviations.

According to Table 3, operating cash flow was best attained in 2014 (8369583.63) and 2015 (8372184.70). The listed companies showed lowest operating activities in 
2018 (4190027.99). However, there was steady or predictable change between the selected years.

Table 2. Stock returns of the manufacturing companies

\begin{tabular}{lllll}
\hline \hline & Minimum & Maximum & Mean & Standard Deviation \\
\hline $\mathbf{2 0 1 3}$ & -.6585 & .4848 & .0394 & .1790 \\
$\mathbf{2 0 1 4}$ & -.5954 & 4.0248 & .1308 & .7308 \\
$\mathbf{2 0 1 5}$ & -.5850 & .5454 & -.1197 & .2518 \\
$\mathbf{2 0 1 6}$ & -.6088 & 1.9677 & .0443 & .5284 \\
$\mathbf{2 0 1 7}$ & -.5238 & 1.8846 & -.0080 & .3767 \\
$\mathbf{2 0 1 8}$ & -.5241 & 1.8933 & -.0246 & .3608 \\
\hline \hline
\end{tabular}

Source: Author.

Table 3: Operating Cash flow

\begin{tabular}{lllll}
\hline \hline & Minimum & Maximum & Mean & Standard Deviation \\
\hline $\mathbf{2 0 1 3}$ & -2561990 & 184905000 & 6361480.00 & 28320030.969 \\
$\mathbf{2 0 1 4}$ & -5572947 & 154521000 & 8369583.63 & 25793587.896 \\
$\mathbf{2 0 1 5}$ & -16043395 & 188259000 & 8372184.70 & 29578227.092 \\
$\mathbf{2 0 1 6}$ & -44011000 & 74559000 & 2872352.79 & 14368563.774 \\
$\mathbf{2 0 1 7}$ & -2162352 & 129411000 & 5917776.93 & 20570247.765 \\
$\mathbf{2 0 1 8}$ & -26026675 & 120875000 & 4190027.99 & 21134480.774 \\
\hline \hline
\end{tabular}

Source: Author.

Investment activities, like the operating activities, showed a skewed pattern. As some years showed high sharp changes (2014/2015), some years showed minimal changes (2017/2018). Strikingly, Table 4 shows negative investment cash flow activities, which might be an indication of rapid investment for the future operations.

Table 4. Investment Cash flow

\begin{tabular}{lllll}
\hline \hline & Minimum & Maximum & Mean & Standard Deviation \\
\hline $\mathbf{2 0 1 3}$ & -86063000 & 6079000 & -2302567.10 & 13184662.834 \\
$\mathbf{2 0 1 4}$ & -69024000 & 1782963 & -2786633.24 & 10559484.538 \\
$\mathbf{2 0 1 5}$ & -159091000 & 3216362 & -4911458.46 & 24233995.845 \\
$\mathbf{2 0 1 6}$ & -25667000 & 3287476 & -2093139.02 & 5182646.265 \\
$\mathbf{2 0 1 7}$ & -113341000 & 1477434 & -5658638.51 & 20601978.814 \\
$\mathbf{2 0 1 8}$ & -96833677 & 17814683 & -5036423.74 & 19097737.607 \\
\hline \hline
\end{tabular}

Source: Author.

The selected companies' financial cash flow activities are mostly negative. The financing activities among these manufacturing companies shows payment activities to debts, especially in 2014 (-5628931.10). However, the companies seem to have retained their financing cash in 2018 (479037.11).

Table 5. Financial Cash flow

\begin{tabular}{lllll}
\hline \hline & Minimum & Maximum & Mean & Standard Deviation \\
\hline $\mathbf{2 0 1 3}$ & -207226000 & 5958254 & -5412432.75 & 31657212.992 \\
$\mathbf{2 0 1 4}$ & -143413000 & 3514077 & -5628931.10 & 22093323.943 \\
\hline
\end{tabular}


The Moderating Role of Earnings Management on the Relationship between Cash Flow Activities and Stock Returns in the Jordanian Manufacturing Firms 1018

\begin{tabular}{lllll}
\hline $\mathbf{2 0 1 5}$ & -100097000 & 18384000 & -3920670.62 & 16499067.221 \\
$\mathbf{2 0 1 6}$ & -105747000 & 12946862 & -2903012.67 & 17135651.081 \\
$\mathbf{2 0 1 7}$ & -74754000 & 36120645 & -2040864.70 & 13911251.379 \\
$\mathbf{2 0 1 8}$ & -89365000 & 99059990 & 479037.11 & 21100930.343 \\
\hline \hline
\end{tabular}

Source: Author.

\subsection{Regression Models}

The association between the outlined variables; stock returns, earnings management and the cash flow activities, according to the stated hypotheses are thus presented. Table 6 shows $\mathrm{R}^{2}$ value of .002 , an indication of $0.2 \%$ of how much of the variance in this analysis got expressed by the cash flow activities. Accordingly, the model presents a low prediction of the association between stock returns and cash flow activities.

Table 6. Summary of multiple regression between stock returns value and cash flow (Operating, investment and financial activities)

\begin{tabular}{llll}
\hline \hline $\mathrm{R}$ & $\mathrm{R}$ Square & $\begin{array}{l}\text { Adjusted R } \\
\text { Square }\end{array}$ & Std. Error of the Estimate \\
\hline .047 & .002 & -.010 & .448 \\
\hline \hline
\end{tabular}

Source: Author.

The ANOVA summary Table 7 presents the overall association between stock returns and cash flow activities. It is evident that the cash flow activities among the selected companies in Amman stock exchange (2013-2018) record insignificant level of variance in stock returns $\left\{\mathrm{F}(3,254)=.185, \mathrm{p}=.906, \mathrm{R}^{2}\right.$ Adjusted $\left.=-.010\right\}$.

Table 7. ANOVA summary of the regression analysis

\begin{tabular}{llllll}
\hline \hline & $\begin{array}{l}\text { Sum of } \\
\text { Squares }\end{array}$ & Df & Mean Square & F & Sig. \\
\hline Regression & .112 & 3 & .037 & .185 & $.906^{\mathrm{b}}$ \\
Residual & 50.989 & 254 & .201 & & \\
Total & 51.100 & 257 & & & \\
\hline \hline
\end{tabular}

Source: Author.

Operating cash flow ( $\mathrm{p}=.513)$, investing cash flow $(\mathrm{p}=.502)$, and financing cash flow activities $(\mathrm{p}=.494)$ do not present ant statistical significant effect on the stock returns of the selected companies. Regarding the outlined hypotheses, the statistical analysis confirm that operational cash flow of the company does not have a significant impact on the value of stock returns; the investment cash flow of the company does not have a significant impact on the value of stock returns, and the financial cash flow of the company does not have a significant impact on the value of stock returns. 
Table 8. Regression Coefficient

\begin{tabular}{llllll}
\hline \hline & \multicolumn{4}{l}{ Unstandardized Coefficients } & \multicolumn{2}{l}{$\begin{array}{l}\text { Standardized } \\
\text { Coefficients }\end{array}$} \\
\cline { 2 - 6 } & $\mathrm{B}$ & Std. Error & Beta & $\mathrm{t}$ & Sig. \\
\hline (Constant) & .011 & .029 & & .377 & .707 \\
Operating Cash flow & $2.407 \mathrm{E}-009$ & .000 & .128 & .655 & .513 \\
Investing Cash flow & $1.974 \mathrm{E}-009$ & .000 & .074 & .673 & .502 \\
Financial Cash flow & $2.320 \mathrm{E}-009$ & .000 & .110 & .686 & .494 \\
\hline \hline
\end{tabular}

Source: Author.

From Tables 6, 7 and 8, earnings management does not moderate the relationship between the operating cash flows and stock returns. This observation among the Jordanian firms could arise from the non-linear relationships between stock returns and the operating cash flow activities (Table 8). Whereas many previous researchers already asserted the inherent relationship between operating cash flow activities and stock returns (Jansen, 2020; Lee, 2012; Farshadfar and Monem, 2013), this study reports otherwise. Indeed, the relationship between the two seem to depend on other external factors. A study conducted by Santoso (2018) also reported that "operating cash flow directly and indirectly has no effect on stock returns" (p. 108). The missing link, as confirmed in this study; therefore, backs up the inability of earnings management to modulate the relationships between operating cash flow and stock returns. The case is classic to the illustration by Bazrafshan (2016) where the management engages in the opportunistic behavior to raise their stock prices for better profit, but the companies' liquid transitions fail to respond.

Further testing of the hypothesis (Table 10) showed statistically insignificant association between earnings management and the relationship between operating cash flows and stock returns $(\mathrm{p}=.752)$; investment cash flows and stock returns $(\mathrm{p}=.502)$, and financial cash flows and stock returns $(\mathrm{p}=.941)$. Hence, the study accepts the fourth, fifth and sixth null hypotheses.

Table 9. Moderating effects of earnings management

\begin{tabular}{|c|c|c|c|c|c|}
\hline & $\begin{array}{l}\text { Unstandardiz } \\
\text { Coefficients }\end{array}$ & & $\begin{array}{l}\text { Standardize } \\
\mathrm{d} \\
\text { Coefficients } \\
\end{array}$ & & \\
\hline & $\mathrm{B}$ & $\begin{array}{l}\text { Std. } \\
\text { Error }\end{array}$ & Beta & $\mathrm{t}$ & Sig. \\
\hline (Constant) & .010 & .030 & & .324 & .746 \\
\hline Discretionary accruals & $-1.589 \mathrm{E}-009$ & .000 & -.039 & -.295 & .768 \\
\hline Operating Cash flow & 3.783E-009 & .000 & .201 & .903 & .367 \\
\hline Investing Cash flow & 2.450E-009 & .000 & .092 & .655 & .513 \\
\hline Financial Cash flow & $3.240 \mathrm{E}-009$ & .000 & .153 & .771 & .441 \\
\hline $\begin{array}{l}\text { Operating Cash flow } \\
\text { *Discretionary Accruals }\end{array}$ & $1.000 \mathrm{E}-013$ & .000 & .136 & .316 & .752 \\
\hline
\end{tabular}


The Moderating Role of Earnings Management on the Relationship between Cash Flow Activities and Stock Returns in the Jordanian Manufacturing Firms

\begin{tabular}{lccccc}
\hline $\begin{array}{l}\text { Investment Cash flow } \\
\text { *Discretionary Accruals }\end{array}$ & $1.000 \mathrm{E}-013$ & .000 & .082 & .672 & .502 \\
$\begin{array}{l}\text { Financial Cash flow } \\
\text { *Discretionary Accruals }\end{array}$ & $1.000 \mathrm{E}-013$ & .000 & .022 & .074 & .941 \\
\hline \hline
\end{tabular}

Source: Author.

Earnings management does not moderate the relationship between investment cash flows and stock returns (Table 10). The missing relationship can be traced to the dissonance between the companies' investment activities and stock returns. The manufacturing firms seem to hold independent investment activities away from the regular business operations, thereby giving the managers the opportunity to perform manipulations of the financial statements. Despite such observation, Kroes and Manikas (2014) reported an inexorable tie between the investment cash flow activities, amidst other financial operations, and stock returns.

However, the previous literature show that investment cash flow can take different effects on the stock returns, and sometimes produce no noticeable effect. Even though this study did not observe a statistically significant effect, Utomo and Pamungkas (2018) reported that investment cash flow activities produce a negative effect on stock returns.

Earnings management does not moderate the relationship between financial cash flows and stock returns. This observation is linked to the reported disconnection between the financial cash flow of the companies and the value of stock returns. The relationship in this case negates the illustration presented by Collins, Hribar and Tian (2014) who show that higher financial cash flow reflects the companies' increased funding and higher profits and stock returns. Subsequently, according to the same illustration, the choice of the manager to inflate the stock prices would depend on the financial cash flow. However, in the case of Jordanian firms listed in Amman stock exchange in the period 2013-2018, the managers' choice to modify the stock prices in the market seem not to depend on the financial cash flow activities, and stock returns.

\section{Conclusions}

The listed manufacturing firms do not have a predicable performance for the period 2013-2018. Moreover, the statistical outcomes show that earnings management do not have a significant moderating role in the relationship between cash flow activities and stock returns among the listed manufacturing firms listed in Amman stock exchange for the period 2013-2018.

However, some restrictions might affect the generalization of the outlined outcomes. First, this study only relied on the manufacturing companies that are listed in Amman stock exchange for the period 2013-2018. Second, earnings management 
was generated strictly based on the modified Jones model (1995) despite the diverse approaches, currently available in the market.

\section{References:}

Abbadi, S.S., Hijazi, Q.F., Al-Rahahleh, A.S. 2016. Corporate governance quality and earnings management: Evidence from Jordan. Australasian Accounting, Business and Finance Journal, 10(2), 54-75.

Abed, S., Al-Attar, A., Suwaidan, M. 2012. Corporate governance and earnings management: Jordanian evidence. International Business Research, 5(1), 216.

Al-Shattarat, H. 2016. Assessing the application of International Accounting Standards (IAS) in Jordan: factors explaining non-compliance. Journal of Modern Accounting and Auditing, 12(7), 17-27.

AL-Qatamin, K.I., Salleh, Z. 2020. Overview of the audit profession in Jordan: Review the change and development of the profession. International Journal of Business Marketing and Management (IJBMM), 5(2), 33-38.

Alzoubi, E.S.S. 2016. Ownership structure and earnings management: evidence from Jordan. International Journal of Accounting \& Information Management, 24(2), $135-161$.

Armein, R.A. 2012. Analisis Kasus Laporan Keuangan PT. Indofarma Tbk. Kasus Laporan Keuangan, 4(3), 19-20.

Banimahd, B., Aliabadi, M. 2013. A study on relationship between earnings management and operating cash flows management: Evidence from Tehran Stock Exchange. Management Science Letters, 3(6), 1677-1682.

Beneish, M.D., Lee, C.M., Nichols, D.C. 2013. Earnings manipulation and expected returns. Financial Analysts Journal, 69(2), 57-82.

Bhaumik, S.K., Gregoriou, A. 201. 'Family'ownership, tunnelling and earnings management: A review of the literature. Journal of Economic Surveys, 24(4), 705-730.

Bradshaw, M.T., Richardson, S.A., Sloan, R.G. 2006. The relation between corporate financing activities, analysts' forecasts and stock returns. Journal of accounting and economics, 42(1-2), 53-85.

Collins, D.W., Hribar, P., Tian, X.S. 2014. Cash flow asymmetry: Causes and implications for conditional conservatism research. Journal of Accounting and Economics, 58(23), 173-200.

Cupertino, C.M., Martinez, A.L., Costa Jr, N.C.A.D. 2016. Consequences for future return with earnings management through real operating activities. Revista Contabilidade \& Finanças, 27(71), 232-242.

Dickinson, V. 2011. Cash flow patterns as a proxy for firm life cycle. The Accounting Review, 86(6), 1969-1994.

Farshadfar, S., Monem, R. 2013. The usefulness of operating cash flow and accrual components in improving the predictive ability of earnings: a re-examination and extension. Accounting \& Finance, 53(4), 1061-1082.

Gulzar, M.A. 2011. Corporate governance characteristics and earnings management: Empirical evidence from Chinese listed firms. International Journal of Accounting and Financial Reporting, 1(1), 133.

Gunny, K.A. 2010. The relation between earnings management using real activities manipulation and future performance: Evidence from meeting earnings benchmarks. Contemporary accounting research, 27(3), 855-888.

Habib, A. 2010. Prediction of operating cash flows: further evidence from Australia. Australian Accounting Review, 20(2), 134-143. 
Hackbarth, D., Haselmann, R., Schoenherr, D. 2015. Financial distress, stock returns, and the 1978 Bankruptcy Reform Act. The Review of Financial Studies, 28(6), 1810-1847.

Hastuti, C.S.F., Arfan, M., Diantimala, Y. 2018. The Influence of Free Cash Flow and Operating Cash Flow on Earnings Management at Manufacturing Firms Listed in the Indonesian Stock Exchange. International Journal of Academic Research in Business \& Social Sciences, 8(9), 1133-1146.

Healy, P.M., Wahlen, J.M. 1999. A review of the earnings management literature and its implications for standard setting. Accounting horizons, 13(4), 365-383.

Jansen, B.A. 2020. Cash Flow Growth and Stock Return. Working papers 202004, Middle Tennessee State University, Department of Economics and Finance.

Kroes, J.R., Manikas, A.S. 2014. Cash flow management and manufacturing firm financial performance: A longitudinal perspective. International Journal of Production Economics, 148, 37-50.

Kuhn, J.R., Sutton, S.G. 2006. Learning from WorldCom: Implications for fraud detection through continuous assurance. Journal of Emerging Technologies in Accounting, 3(1), 61-80.

Lee, L.F. 2012. Incentives to inflate reported cash from operations using classification and timing. The Accounting Review, 87(1), 1-33.

Luo, M. 2008. Unusual operating cash flows and stock returns. Journal of accounting and public policy, 27(5), 420-429.

MacCarthy, J. 2017. Using Altman Z-score and Beneish M-score models to detect financial fraud and corporate failure: A case study of Enron Corporation. International Journal of Finance and Accounting, 6(6), 159-166.

Man, C.K., Wong, B. 2013. Corporate governance and earnings management: A survey of literature. Journal of Applied Business Research, 29(2), 391-418.

Roychowdhury, S. 2006. Earnings management through real activities manipulation. Journal of accounting and economics, 42(3), 335-370.

Santoso, A. 2018. Factors affecting operating cash flow to stock return through stock price. JMBI UNSRAT (Jurnal Ilmiah Manajemen Bisnis dan Inovasi Universitas Sam Ratulangi), 5(2), 108-128.

Sun, L., Rath, S. 2010. Earnings management research: a review of contemporary research methods. Global Review of accounting and Finance, 1(1), 121-135.

Utomo, D., Pamungkas, I.D. 2018. Cash Flow Activities and Stock Returns in Manufacturing of Indonesia: A Moderating Role of Earnings management. Academy of Accounting and Financial Studies Journal, 22(6), 1-10.

Yen, J.W., Chun, L.S., Abidin, S.Z., Noordin, B.A.A. 2007. Earnings management practices between government linked and Chinese family linked companies. International Journal of Economics and Management, 1(3), 387-406. 